История российско-китайских отношений

俄中关系历史

The History of Russian-Chinese Relations

YAK $(47+510)(09)$

DOI: 10.17150/2587-7445.2019.3(4).28-37

Власти Забайкальской области

и китайские иммигранты: начало XX века

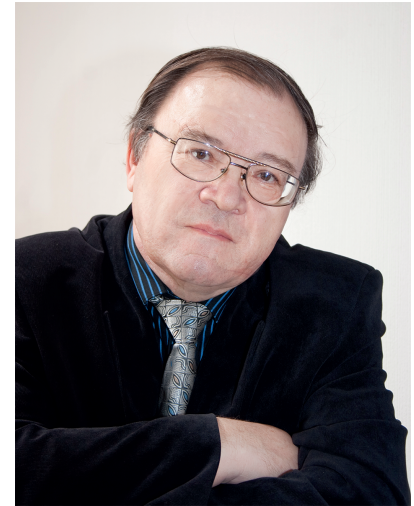

\section{В.И. Косых}

Забайкальский государственный университет,

г. Чита, Россия

Аата поступления:

13.05.2019

Аата принятия к печати:

18.12.2019

Аата онлайн-размещения:

28.12.2019
Аннотация. Рассматриваются взаимоотношения, сложившиеся между различного властями Забайкальской области и прибывшими сюда китайскими иммигрантами в начале XX в. Автор анализирует причины, побудившие подАанных Поднебесной к появлению на территории Российской империи. В работе указывается, что китайцы прибывали сюАа по самой простой причине - чтобы прокормить свои семьи, оставшиеся Аома, и, если получится, открыть в Забайкалье свое дело, как некоторые их соотечественники, осевшие в России.

В статье подчеркивается, что китайцы в Забайка^ье брались абсолютно за любую работу, не гнушаясь самой черной, не требующей квалификации, причем за ту оплату, от которой отказывались россияне. По мнению автора, они преуспели в огородничестве, поскольку постоянно уАивляли забайкальцев тем, что у них раньше всех появлялись свежие овощи, которые быстро раскупались.

Много подАанных Поднебесной трудились на забайкальских золотых приисках, строительных площадках, прокладке Аорог, включая и Забайкальскую железную Аорогу, занимались торговлей, реализуя продукцию, вывозимую с родины. Они арендовали участки земли у местного населения, занимаясь огородничеством. Можно полагать, что подобное трудолюбие могло снискать уважение забайкальцев.

ПравАа, взаимоотношения властей с частью китайцев явно не складывались. Основная их масса прибывала в Забайкалье и проживала здесь по национальным паспортам или виду на жительство, которое выАавалось российскими консульствами в Китае, мибо по месту их пребывания и проживания. Подобные Аокументы китайцам наАлежало постоянно иметь с собой. ОАнако не все китайцы прибывали легально: часть из них проникала без разрешающих документов, что Аоставляло немало головной боли чиновникам Министерства иностранных дел России, военным и гражАанским властям Сибири, Забайкалья, Приморья, ви- 
Аевшим в этом "желтую опасность". Беспаспортных, не имевших виАа на жительство не пропускали через российскую границу или высылали в Китай, запрещалось (с 1910 г.) принимать на казенные работы.

Кмючевые слова. Забайкалье, полиция, китайцы, паспорт, виА на жительство, нелегалы.

\section{二十世纪初，后贝加尔政府与中国移民}

\section{Kosykh V.I.}

后贝加尔国立大学

赤塔，俄罗斯联邦

结稿日期：2019年5月13日

出版日期：2019年12月18日

网上出版日期：2019年12月28日
摘要。本文介绍了 20 世纪初，后贝加尔地区的各个部门 与到达这里的中国移民之间的关系。作者分析了促使中国 公民来到俄罗斯境内的原因。分析表明，中国人来到这里 的最直接的原因是供养留守在故乡的家人，并在条件允许 的情况下，像在俄罗斯定居的其他同胞一样，在后贝加尔 开始工作。

这篇文章强调了中国华人从事的各种工作被鄙视为 黑户，而且俄罗斯人拒绝支付这笔钱。根据作者的说法， 他们从事了果蔬工作，因为他们的蔬菜新鲜度使贝加尔湖 的居民惊讶，所以果蔬很快就卖光了。

中国的许多公民在后贝加尔湖的金矿、建筑工地、道路 铺设，包括后贝加尔湖从事贸易，销售从中国出口的产品 的铁路项目。他们从当地居民那里租了土地，从事种植。 可以肯定的是，这种勤奋赢得了后贝加尔人的尊重。

显然，政府部门与部分中国人之间的问题没有解决。 他们中的大多数人到达了特兰拜卡利亚，并根据国家护照 或俄罗斯驻中国领事馆签发的居留证在这里居住，或在其 居住地居住。中国人应始随时随身携带此类文件。但是， 并不是所有的中国人都是合法到达的：其中一些人未经许 可就入境了，这给俄罗斯外交部官员，西伯利亚，特贝卡 利亚，滨海边疆区的西伯利亚军事和民政部门的官员们带 来了很多麻烦，他们认为这是 “黄色危险”。没有居留证 的非护照持有人的中国人不允许越过俄罗斯边境或被驱逐 回中国，从1910年开始，政府工作开始禁止接受。

关键词。后贝加尔，警察，中国人，护照，居留证，非法 移民者。

\section{Authorities of Zabaikalye Oblast and Chinese Immigrants: Early XX Century}

\section{Kosykh V.I.}

Zabaikalye State University

Chita, Russia

Received: May 132019

Accepted: December 182019

Available online: December 282019
Abstract. The paper examines interrelations developed between various authorities of Zabaikalye Oblast and Chinese immigrants who arrived here in early XX century. The author analyses the causes that had motivated the subjects of the Heavenly Empire to appear on the territory of the Russian Empire. The paper shows that the Chinese arrived here due to the simplest reason - in order to provide for their families, 
that had stayed at home, and with any luck, to open their businesses in Zabaikalye, like their compatriots who had settled down in Russia.

The article underlines that the Chinese absolutely took up any job, being not above the most unskilled labor, what's more, for the same payment the Russians would refuse. In the author's opinion, they made great strides in market gardening as they constantly surprised the Zabaikalye people with their coming out with fresh vegetables to be bought up quickly.

Many subjects of the Heavenly Empire labored at the Zabaikalye gold workings, construction sites, including the Zabaikalye railway road, engaged in trade, marketing the products carried out from the motherland. They leased patches of land from local population, doing market gardening. One may believe that such industriousness could win respect of the Zabaikalye people.

The truth was that interrelations of the authorizes with part of the Chinese evidently did not develop. Their major mass arrived to Zabaikalye and lived here with their national passports or residence permits, issued by Russian consulates in China or on the place of their stay and living. The Chinese were supposed to have similar documents constantly with them. But not all Chinese arrived legally: part of them penetrated without permitting documents, which caused headaches to civil servant of the Russia' Ministry of Foreign Affairs, to the military and civil authorities of Siberia, Zabaikalye, Primorye, who saw "yellow danger" in it. Those having no passports or residence permits were not allowed to pass through the border or sent back to China, they were forbidden (since 1910) to be hired for state-owned jobs.

Keywords. Zabaikalye, police, Chinese, passport, residence permit, undocumented migrants.

K концу XIX в. в Забайкалье не существовало территорий компактного расселения китайцев. Большинство из них находилось в крае временно, занимаясь сезонными работами и промыслами, образовывая отдельные районы или точки в городах и селах.

Основной поток китайских иммигрантов направлялся в Приморье, Забайкалью Аоставались лишь его “брызги", хотя Аоля китайцев в общих цифрах населения края являлась заметной. В большинстве своем они прибывали из сосеАней Маньчжурии, горазАо меньше из Приморья и Приамурья гг. ВлаАивостока и Благовещенска ${ }^{1}$.
Проживали китайцы в Забайкалье по национальным паспортам или по виду на жительство (билету). ПослеАний выдавался российскими консульствами в Китае, либо по месту их пребывания и проживания. Например, Читинское городское полицейское управление выдавало указанный Аокумент сроком на 1 гоА. Уместно привести текст подобного свилетельства: "Главное Железнодорожное Аипломатическое бюро Хэйлунцзянской провинции в г. Харбин 19 апреля 4 г. Китайской Республики № 301 Свидетельство. Выдано китайскому подАанному рабочему Чжоо-Аин-Чин, отправляющемуся в пределы Российской империи в г. Читу, со-

${ }^{1}$ ГАЗК. Ф. 26. ОП. 1. А. 393. ^. 17. 
гласно его просьбе с предоставлением фотографической карточки и Авух экземпляров: 1 экземпляр хранится при Аипломатическом бюро; 2 экземпляр - засвидетельствованный с приложением казенной печати и приклеен к настоящему свидетельству. В случае предъявления свидетельства без карточки, таковое недействительно. Свидетельство Аействительно сроком на ОАин гоА" ${ }^{2}$.

По истечении годичного срока билеты (свидетельства) надлежало продлевать. Отметим, что после 1910 г. к свидетельствам в обязательном порядке прилагалась фотография влалельца, без которой Аокумент считался недействительным.

При визировании своих национальных паспортов и получении российских билетов китайцы выплачивали различные сборы основные, штрафные, Аополнительные, гербовые. Так, в течение 1911 г. в Забайкальской области за визирование национальных паспортов и получение российских билетов китайцы уплатили следующие сборы: налог - 1470 руб. 60 коп., гербовый 703 руб. 50 коп., канцелярский сбор 277 руб. 20 коп., штрафные - 375 руб. (всего 2926 руб.) ${ }^{3}$.

Число прибывающих в Забайкалье китайцев на $10 \%$ превышало число убывающих на родину. Они реАко задерживались зАесь, проживали чуть больше года, скопив опреАеленную сумму, возвращались на родину к своим семьям. В связи с постоянными перемещениями их учет на территории Забайкалья являлся Аелом трудным. Уместно привести некоторые факты. Так, в Маккавеевском станичном правлении к марту 1911 г. отмечено 11 китайцев, в течение мая сюда прибыл еще один, и убыло трое. На июнь 1911 г. здесь оставалось трое китайцев ${ }^{4}$.

В станице Титовской того же правления проживали 8 китайцев (все - рабочие), в Титовском выселке еще 19 (также рабочие), в поселке Атамановском - сразу 40 (все 67 чел. - рабочие). В станице Титовской китайцы занимались исключительно

\footnotetext{
2 ГАЗК. Ф. 8. ОП. З. А. 124. ^. 10.

${ }^{3}$ ГАЗК. Ф. 26. ОП. 1. А. 393. ^. 25.

4 ГАЗК. Ф. 26. ОП. 1. А. 393. ^. 16-16 ОБ; ГАЗК. Ф. 19. П. 1. А. 257. ^. 21, 49, 66.
}

огородничеством, поражая местное насемение чрезвычайно ранним выращиванием лука, реАиски, огурцов и Ар. Реализация плодов земных приносила китайцам 1650 руб. прибыли (естественно, без вычета расходов).

Китайцы на выселках в основном трудились на вокзале, в пос. Атамановском занимались распиловкой аров от поАряАчика крестьянина Григорьева из Алексанаровской волости ${ }^{5}$.

Пристав Нерчинского окружного ведомства Кабинета Его Императорского Величества Аокладывал в канцелярию Забайкальского статистического комитета следующее: в станице Новотроицкой работали 40 китайцев, еще олин - в пос. Казаково, на Урульгинском промысле - пятеро, на Приаргунском промысле-шестеро (всего 75 рабочих)

В пос. Галкинское Размахнинской станицы трудились разнорабочие ЧинЦай и Ю-Фан, чей заработок составля^ 10-15 руб. в месяц?

Тыргетуевское волостное правление Читинского округа сообщало, что на 1 сентября 1900 г. в с. Бальзинском проживал один китаец, православный и женатый на русской, имевший Аевятерых Аетей (пятерых мальчиков и четырех Аевочек). В с. Аарасунском работали трое китайцев, в с. Новодоронинское - один китаец-торговец, располагавший имуществом, оцененным в 1500 руб. Отметим, что китаец в с. Бальзинском также занимался торговлей и располагал имуществом на ту же сумму 8 .

Свой капитал китайцы наживали на торговых операциях, реализуя товары, привозимые с родины. Его обычно составляли различные ткани, женская бижутерия, кожаная обувь, фрукты, американский технический спирт и Ар. Аобавим сюАа и то, что они не отказывались ни от какой работы, которой в Забайкалье хватало.

Они неплохо прижились зАесь, устраивали и свою семейную жизнь. Некоторые волостные, станичные правления в отчетах

\footnotetext{
${ }^{5}$ ГАЗК. Ф. 19. ОП. 1. А. 91. ^. 131, 138.

${ }^{6}$ ГАЗК. Ф. 19. ОП. 1. А. 91. ^. 173-174.

ГАЗК. Ф. 138. ОП. 1. А. 135. ^. 2.

8 ГАЗК. Ф. 19. ОП. 1. А. 91. ^. 177, 196.
} 
Забайкальскому статистическому комитету почему-то относияи к китайцам детей от браков послеАних с россиянками.

Сведения о прибывших и проживавших китайцах поступали в вышеуказанный комитет не только из уезАов - отчитывались переА ними и власти г. Читы. Статистика учитывала не только количество подаанных Поднебесной, но и среАу их деятельности. Так, в веАомости о китайцах, проживающих в г. Чите на 1 сентября 1900 г., значились 240 торговцев (213 “торгующих" и 27 приказчиков), 63 плотника и разнорабочих, 20 рабочих кожевенных заводов, 128 - кирпичных заводов, 60 - огородников (всего 511 чел.) ${ }^{9}$.

По Аанным Забайкальского областного статистического комитета на 1 сентября 1900 г. в области проживали 4973 официально зарегистрированных китайца ${ }^{10}$. Все они располагали необходимыми Аля этого Аокументами.

Правда, Аалеко не все китайцы учитывались вышеуказанным учреждением, поскольку не все правления предоставляли необхоАимые сведения. Так, Куенгское утвержАало, что на местном заводе трудилось значительное число китайцев, хотя конкретных цифр не указало. Аело в том, что руководство преАприятий и жандарм (в его веАении находимись китайцы) в станичное правление точной статистики не преАоставляло.

На 1 сентября 1900 г. на Борщевском винокуренном заводе М.А. Бутина трудились те же китайцы, хотя и неизвестно сколько. Подобное отмечалось и на Колертайском цементном заводе ${ }^{11}$. Можно полагать, что руководство преАприятий, контролировавшее присутствие на них китайцев, не собиралось подавать объективные сведения о них. Тот же начальник 10-го участка службы ремонта пути и зАаний Забайкальской железной Аороги сообщал, что на 1 сентября 1900 г. на 977-1 057-й верстах пути трудился всего-то 41 китаец ${ }^{12}$.

Можно полагать, что мукавил и заведующий Приаргунскими отрядными золотыми промыслами, сообщая, что на 1-е сентября

\footnotetext{
9 Там же. ^. 208.

${ }^{10}$ ГАЗК. Ф. 19. ОП. 1. А. 91. ^. 205, 206 ОБ.

11 Там же. ^. 129.

12 Там же. ^. 142, 142 ОБ.
}

1900 г. на промысле по реке Архипов (так в тексте-В.К.) работали всего шестеро поААанных Поднебесной ${ }^{13}$.

Унаургинское волостное правление поАробно информировало статистический комитет, что на 1 октября 1900 г. в волости труАились шестеро китайцев в возрасте от 26 Ао 39 лет, все бессемейные. Из них Ван Вын-хо, Хеньтуцинь, Ван Чжан Чжун в выселке Могойтуевском (при станции ААриановка) арендовали у крестьянина С. Ушакова 1425 кв. саженей земли за 100 руб. в гоА, занимались огородничеством. Син Чан-Цунь, Чжан-Иань и ^и-Син арендовали в том же выселке у крестьянина Г. Крюкова 839 кв. саженей земли за 60 руб. в гоА ${ }^{14}$.

Забайкальские предприниматели нанимали китайцев потому, что, во-первых, русские на ^юбую работу не шли, считая ее слишком уж тяжелой. Во-вторых, русские рабочие всегАа требовали повышенной платы, китайцы соглашались на обычную ${ }^{15}$.

Землю те же забайкальцы сАавали китайцам в аренду потому, что, во-первых, она имелась в излишнем количестве и русские ее не особенно арендовали. Во-вторых, китайцы прекрасно обрабатывали земельные участки, Аобивались хороших урожаев, выплачивая Ао 25 руб. с Аесятины в гоА ${ }^{16}$.

Правда, признавая превосходные качества китайца-земледельца, купца, промысловика, отАавая и совершенно справеАливо Аолжное потрясающему трудолюбию китайского работника, русские тем не менее с плохо скрываемым презрением относились к ним. Естественно, и китайцы воспринимали русских соответственно

Известный российский революционер ^.Г. Аейч, живший в г. Благовещенске, отмечал: "... В среде малокультурных слоев нашего населения китайцы и маньчжуры не пользовались особо симпатией, низшие слои видели в них преАставителей чуждой национальности, упорно избегающей слиться с русской... Кроме того, в них русские рабочие видели опасных Аля себя конкурентов..." [1, с. 57].

\footnotetext{
${ }^{13}$ Там же. ^. 159.

14 ГАЗК. Ф. 24. ОП. 2. А. 184. ^. 20-23.

15 Там же. $\Lambda .10$.

${ }^{16}$ Там же. ^. 11 ОБ.
} 
После восстания ихэтуаней поток китайцев в Россию вообще и в Забайкалье в частности заметно уменьшился. ОАнако после поражения России в войне с Японией 1904-1905 гг. российские власти и общественность выражали серьезную обеспокоенность тем, чтобы новый наплыв китайцев не привел в итоге к потере контроля наА восточными окраинами России. Кроме того, среди китайской общины в Приамурье широко распространялись преАставления о том, что именно они, китайцы, являются истинными хозяевами обширного края. Понятно, что подобные слухи, при наличии определенных обстоятельств, вполне могми бы прижиться и среАи китайской общины в Забайкалье [2, с. 68].

ПослеАняя регулярно пополнялась. Можно полагать, что китайцы манкировали российскими законами. Они проживали в России фактически вне паспортного контроля. Тайный переход российско-китайской границы они давно отработали за счет Аоставки сюда ханшина или недоброкачественного американского технического спирта, переправляя в Китай золото. ПравАа, и россияне не единожАы подобным же образом с разными мелочными грузами нарушали ту же границу. Этот поток не смогли перекрыть ни российские пограничники, ни таможенники.

В целях пресечения подобного российские власти устраивали настоящие облавы на территории страны. В Забайкалье в 1905-1912 гг. удалось обнаружить «безбилетных" китайцев, не имевших ни визированных паспортов, ни видов на жительство. В этом случае нелегалов просто высылали за пределы Российской империи. К сожалению, точных сведений о количестве высланных "безбилетных" китайцев пока обнаружить не удалось ${ }^{17}$.

В 1905-1911 гг. в Чите полиция выявила 1547 нелегально ("безбилетных») проживающих китайцев ${ }^{18}$. Позже, в ночь на 5 марта 1916 г., команда пристава 2-й части г. Читы задержала 12 китайцев без вила на жительство, который наллежало носить при себе обязательно: отсутствие его квалифицирова-

\footnotetext{
${ }^{17}$ ГАЗК. Ф. 26. ОП. 1. А. 393. А. 12, 13, 13 ОБ.

${ }^{18}$ Там же. ^. 27.
}

^ось как серьезное нарушение российского законодательства. Они же оказались без определенного рода занятий, всех их незамеАлительно выдворили из России ${ }^{19}$.

Масса китайцев-нелегалов трудилась на крупных строительных объектах, предприятиях горнодобывающей отрасли, золотых приисках. Полиция организовывала в таких местах ночные и дневные облавы, после чего обнаруженные здесь нелегалы-китайцы высылались на родину. Правда, имелись искиючения следующего порядка, Аействовавшего и в Забайкалье: если за кого-либо из них ходатайствовали работодатели, то помицией им выдавался виА на жительство, они получали разрешение остаться на работе ${ }^{20}$.

Сверхлешевый труд китайцев, их безотказность заниматься им побужАали преАпринимателей и, в частности, золотопромышленников, негласно оказывать помощь китайцам-нелегалам.

Негативные стороны (сверхаешевый труд, безотказность, безропотность и Ар.) жизни китайских общин (от Забайкалья и Ао Аальнего Востока) созАавали устойчивое представление россиян о "китайском засилье». Так, генерал А.И. Куропаткин отмечал: "... Ныне огромная эмигрантская волна.. перекатывается через границу и смешивается с русским населением, созАавая Аля него конкуренцию во всех видах труда. Если бы упразАнить русско-китайскую границу и Аопустить свободное переАвижение в Сибирь китайцев наравне с русскими правами - сибирские местности могли бы в короткое время окитаиться, а русские стами бы вытесняться за Урал" [2, с. 66].

Существовали опасения и Аругого поряАка: на китайцев россияне нередко смотреми как на "развеАчиков" или "проводников" потенциального вражеского войска. Можно только сожалеть, что благодаря известному благодушию и безалаберности российских властей на местах, китайцев Аопускали даже на строительство укреплений и Аругих военных объектов. Получалось странное, хотя и обычное Аля России: "В места, куда русского офицера не Аопустят никоим образом,

\footnotetext{
19 ГАЗК. Ф. 24. ОП. 1. А. 523. ^. 10.

${ }^{20}$ ГАЗК. Ф. 1(0). ОП. 1. А. 14976. ^. 7-12, 17.
} 
китайцы проникают вполне свободно". РяАовому российскому обывателю преАставмяется вполне вероятным Араматический вариант всеобщего восстания китайцев по еАиному сигналу с послеАующим превращением их в "тыловое войско" [2, с. 68].

Подобные опасения имели поА собой основу и этот вывод четко прослеживался в переписке военных властей Забайкалья, Приамурья, Иркутска. Так, военный губернатор Забайкальской области в письме от 2 мая 1909 г. за № 759 сообщал читинскому полицмейстеру: "За последнее время стало наблюдаться массовое передвижение по Забайкальской железной дороге китайцев. По мнению железнодорожных агентов, это не китайские рабочие, а войска: все они хорошо, чисто и однообразно одеты, следуют в однообразно образцовом порядке, соблюАают полную тишину, реАко выходят из вагонов".

Поскольку на строительство амурской железной Аороги запрещалось принимать китайских рабочих, "А^я нужА же приисков такое количество слишком велико, то упомянутый массовый наплыв в наши пределы незваных иностранцев обращает на себя внимание...". И Ааже указывалось: "... Предписываю донести мне сколько во вверенном Вам уезде находится китайцев; в какой местности отАельно чем занимаются и т.п.» ${ }^{21}$.

Отметим, что впослеАствии эскалация и передвижение китайских войск будут повсеместно наблюдаться на протяжении китайской границы - от Забайкалья Ао ВлаАивостока. По той же причине нелегальное пересечение границы китайцами стало настоящей "головной болью" Аля местных российских властей.

Иркутский генерал-губернатор в письме от 10 февраля 1907 г. за № 70 рекомендовал военному губернатору Забайкальской области "сделать соответствующее распоряжение подведомственным Вам мицам, чтобы все при переходе китайскими подАанными нашей границы, требовали от них паспорта, визированные нашими консулами и Консульскими преАставителями в Мон-

21 ГАЗК. Ф. 26. ОП. 1. А. 260. ^. 25-27. голии и Маньчжурии, миц, не имеющих визированных паспортов, не пропускать в пределы России..." 22.

Массовое и зачастую бесконтрольное перемещение китайцев по России, включая Сибирь, Забайкалье и Аальний Восток, стави^о власти на местах переА необходимостью по-настоящему строгого учета и регистрации их переАвижения. Так, военным губернаторам Забайкальской области в распоряжении от 22 июня 1907 г. за № 539 к уезаным начальникам и полицмейстерам предписывамось: " ... Представлять ежемесячно, начиная с 1-го июля сего года в Штаб Иркутского Военного округа сведения о всех проезжающих и проживавших в подвеАомственных Вам районах, китайских подаанных. Сведения эти Аолжны заключать в себе данные: откуАа и когАа прибыло мицо, чем занимается и сколько лет имеет от роду" ${ }^{23}$. Можно полагать, что военный губернатор поставил переА своими чиновниками труАную задачу.

Читинский полицмейстер получал сведения о числе проживающих в городе китайцев от полицейских наАзирателей, являющихся начальниками полицейских отАелов. Полученные Аанные он направлял военному или вице-губернатору. Отметим, что в них ощущался явный разнобой. Точно учитывались кишь те китайцы, которые проживали в городе вполне легально, с положенными Аля этого Аокументами и имевшие опредеменный род занятий. Что касается проживавших нелегально, равно как постоянно перемещавшихся по Забайкалью в поисках более-менее постоянной работы и заработка, то они не подАавались полицейскому учету. Аа и послеАние сами указывали в отчетах, что точными сведениями о числе немегальных и постоянно перемещающихся по области китайцах они не располагают ${ }^{24}$.

В 1911 г. Аля противодействия наплыву подАанных Поднебесной власти огромного Аальневосточного региона России совместными усилиями сумели выработать ряА общих ограничительных мер. В них преАлагалось следующее: “... 1. Всех китай-

\footnotetext{
22 ГАЗК. Ф. 26. ОП. 1. А. 495. ^. 21.

${ }^{23}$ ГАЗК. Ф. 26. ОП. 1. А. 233. ^. 11.

${ }^{24}$ ГАЗК. Ф. 26. ОП. 1. А. 393. ^. 25.
} 
ских подАанных, прибывших на границу, без своих национальных паспортов, визированных нашими консульствами, не Аопускать в пределы России...

2. Обнаруживаемых в областях китайских подаанных, не имеющих ни национальных визированных паспортов, ни русских билетов, немедленно выдворять на родину.

3. Китайские подАанные, которые уже водворились в областях и проживают по оАним только русским билетам без национальных визированных паспортов, билетов этих не продлевать.

4. ^иц, принявших на работы беспаспортных китайцев или с просроченными билетами, а также предоставивших им пристанище, привлекать к законной ответственности..." ${ }^{25}$. Судя по всему, контроль за беспаспортными и безбилетными китайцами, а также допускавшими попустительство в этом отношении российскими преАпринимателями, мог усилиться.

Чуть раньше, летом 1910 г., с началом работ по строительству межау Кяхтой и Троицкосавском казарм Аля военного ведомства, из Иркутска, Верхнеудинска и Читы прибы^о несколько сот китайцев из провинций Маньчжурия и ШаньАун. Все они являлись чернорабочими, имели национальные паспорта, завизированные во Владивостоке. За всей этой массой Кяхтинский пограничный комиссар и Цзаргучей (глава) китайского города Маймачен установили самый строгий контроль. Ава-три раза в месяц они подвергали внезапной проверке всех китайцев в местах их проживания и на рабочих местах. Обнаруженных без паспортов немеАленно выАворяли в Китай, или, при известной благонадежности и поручительстве за них со стороны российских преАпринимателей, снабжали паспортами ${ }^{26}$.

Вскоре решение проблемы нелегальных иммигрантов потребовало не только участия в этом региональных властей, но и принятия закона на государственном уровне. Об этом свидетельствует Аокумент в виАе копии отношения Аепартамента общих Аел MBA России Иркутскому губернатору от 9 марта

\footnotetext{
25 ГАЗК. Ф. 24. ОП. 1. А. 192. ^. 7-7 ОБ.

${ }^{26}$ ГАЗК. Ф. 1 (0). ОП. 1. А. 14796. ^. 13.
}

1912 г. за № 6851. По поручению военного губернатора Забайкальской области от 23 июня 1913 г. за № 4753 документ разослали уездным начальникам, горным исправникам, приставам Нерчинского округа Кабинета Его Императорского Величества и Амурской железной дороги ${ }^{27}$.

В нем, в частности, отмечалось слеАующее: «В виАу принятия мер противодействия наплыва "желтой расы", МВА ... был выработан внесенный в Государственную Ауму проект правил о пропуске в Приамурское генерал-губернаторство и Забайкальскую область и о проживании в них иностранных подАанных. Вместе с тем имелось в виду увеличение штатов местной аАминистрации, полиции, врачей, со специальной целью усилить среАства наАзора наА прибывающими в край китайцами... Аля этого требовалось знать:

1. Количество и плотность населения к настоящему году в Забайкальской области;

2. Распределение иностранцев во возрасту, полу, профессиям.

3.Число неспособных к труду и безработных китайцев.

4. Эксплуатация китайцами русских инородцев, преступность среАи желтого насемения" ${ }^{28}$.

Можно полагать, что власти Забайкальской области, Приамурья и Приморья взАохнули с облегчением, однако законопроект таковым и остался. Свою роль в этом сыграма позиция Министерства иностранных дел России: «Наплыв (китайцев - В.К.) не опасен политически" [2, с. 68].

Приамурский генерал-губернатор в письме от 7 декабря 1913 г. за № 374 напоминал губернаторам Амурской и Забайкальской областей, что "хотя законопроект о воспрещении иностранцам в проживании в полосе отчужАения Амурской железной Аороги наниматься в работники у русских нет оснований, но тем не менее в целях предотвращения наплыва "желтых" ... необходимо принять все меры, Аопускаемые законом, к воспрещению наплыва на нашу территорию. Поэтому следует широко пользоваться статьей 205 (1)

\footnotetext{
${ }^{27}$ ГАЗК. Ф. 26. ОП. 1. А. 393. ^. 1.

${ }^{28}$ ГАЗК. Ф. 26. ОП. 1. А. 393. ^. 2-4.
} 
Уст. преА. и пресс., предоставляющей право губернаторам высылать их за границу" ${ }^{29}$.

Неизвестные трудности связывались с введением паспортной системы на российской границе, особенно в районе Кяхты, и на участке границы с Монголией. Российские власти понимали, что при коренном изменении установленных ранее правил и порядков перехода китайских подАанных российской границы невозможно в кратчайший срок путем оАного мишь опубликования применить их Аля обширной кочевой Монголии. Существовало опасение, что поспешностью в этом вопросе можно вызвать труднопоправимые и неблагоприятные послеАствия Аля России ${ }^{30}$.

На фоне межАународной жизни и приграничных отношений межау Россией и китайской Маньчжурией, регламентированных рядом особых Аоговоров и соглашений, всегАа исполняющихся обеими сторонами, ввеАение паспортной системы Аля китайцев являлось вопросом малозначимым, как не нарушающим никаких установленных изАревне обычаев ${ }^{31}$.

Кяхтинский пограничный комиссар в письме от 12 ноября 1920 г. за № 143 Иркутскому военному губернатору сообщал: "...В общем следует прийти к окончательному выводу, что в данное время к применению на монгольской границе строгих ограничительных мер против наплыва китайцев и самовольного их вторжения к нам, никакой острой надобности не встречается, так как в Россию они иАут не через Монголию, а через Маньчжурию и Забайкалье. Стеснять же китайцев в крупных их фирмах, око$\wedge$ Авухсот лет существующих в Маймачене, сроднившихся с русскими, с которыми они будут вести и ведут общие крупные дела по нашему экспорту в Китай и запаАную Европу, так же нет необходимости. Ао сих пор Маньчжурская аАминистрация в Монголии и китайские крупные фирмы не могут еще оправиться от удара по нашей границе запретительной пошлиной на шелк и Аругое...".

\footnotetext{
29 ГАЗК. Ф. 24. ОП. 1. А. 280. ^. 5.

30 ГАЗК. Ф. 1 (О). ОП. 1. А. 280. ^. 5.

${ }^{31}$ ГАЗК. Ф. 1 (О). ОП. 1. А. 14796. ^. 9.
}

В заключение комиссар отмечал: "... Наше приграничное и инородческое население, несмотря на обширность занимаемых своих земельных участков, крепко охраняют кажАый клочок своей собственности, и в общей своей массе преАставляет собой трудновосприимчивую Аля внеАрения в ней пришлых китайцев» ${ }^{32}$.

Можно полагать, что вышеуказанным сообщением пограничный комиссар из Забайкалья убежАал высокое руководство в Иркутске в том, что нет ничего страшного, что китайцы перебираются в Россию ради работы и заработка, не совершая ничего предосудительного.

Российские власти, вводя паспортную систему и Аругие ограничительные меры, шли на это крайне осторожно, опасаясь испортить отношения с Китаем. Российская торговля, как и китайская, постоянно поААерживали взаимную заинтересованность в сотрудничестве при минимуме ограничительных правил и законов. Именно поэтому ввод каких бы то ни было ограничительных мер бил, прежде всего, по торговым интересам обоих государств.

В политических кругах страны прочно утвержАалось мнение, что сохранение суверенитета России наА Сибирью и Аальним Востоком - это важнейшая проблема, требующая самого серьезного внимания и что основное условие ее решения состоит в более или менее плотном заселении вышеуказанных территорий. Правительство издавало ряд законов, шаг за шагом ограничивающих Аеятельность иностранцев и возможность их оседания и укоренения на территории Забайкалья и Аальнего Востока. Так, в 1910 г. российское правительство запретило наем иностранцев на казенные работы и др. [2, с. 68]. ОАнако полномасштабному осуществлению планов правительства и местных властей в этом вопросе помешала первая мировая война.

\footnotetext{
32 Там же. ^. 10, 17.
} 


\section{Список использованной митературы}

1. Аацышен В. Уссурийские купцы / В. Аацышен // Родина. - 1995. - № 7. C. 54-57.

2. Марин А. Желтый вопрос / А. Марин // Родина. - 1999. - № 1. - С. 66-72.

\section{References}

1. Datsyshen V. Ussuri merchants. Rodina, 1995, no. 7, pp. 54-57. (In Russian).

2. Larin A. Yellow Question. Rodina, 1999, no. 1, pp. 66-72. (In Russian).

\section{Информация об авторе}

Косых Владимир Иванович - кандидат исторических наук, Аоцент кафедры истории историкофилологического факультета ФГБОУ ВО “Забайкальский государственный университет", г. Чита, Россия e-mail: ifotdel@yandex.ru

\section{有关作者的信息}

Vladimir I. Kosykh - 历史学副博士，后贝加尔国立大学历史与语文系，历史教研室的副教授， 赤塔, 俄罗斯联邦, 电子信箱: ifotdel@yandex.ru

\section{Author}

Vladimir I. Kosykh - PhD in History, Assistant Professor, Chair of History, Department of History and Philology, Zabaikalye State University, Chita, Russia: e-mail: ifotdel@yandex.ru

\section{Аия цитирования}

Косых В.И. Власти Забайкальской области и китайские иммигранты: начало XX века / В.И. Косых // Российско-китайские исследования. - 2019. -Т. 3, № 4. - С. $28-37$.

\section{For citation}

Kosykh V.I. Authorities of Zabaikalye Oblast and Chinese Immigrants: Early XX Century . Rossiisko-Kitaiskie Issledovaniya = Russian and Chinese Studies, 2019, vol. 3, no. 4, pp. 28-37. (In Russian). 